\title{
ASSESSING TEACHERS' BELIEFS AND PRACTICES IN RELATION TO THE INTEGRATION OF GRAMMAR AND READING IN FOREIGN LANGUAGE TEACHING IN SECONDARY SCHOOLS IN ETHIOPIA
}

\author{
Gemechis T. Chali ${ }^{1}$, Kimberley Mouvet ${ }^{2} \&$ Miriam Taverniers ${ }^{2}$ - \\ 1 Department of English Language and Literature, Jimma University, Ethiopia \\ 2 Department of Linguistics, Ghent University, Belgium
}

\begin{abstract}
Studies have suggested that teachers' beliefs have a significant influence in language teaching (e.g., Williams and Burden, 1997), i.e. that teachers' beliefs will significantly influence their teaching practice. This study examines teachers' beliefs and practices in relation to the integration of grammar and reading in foreign language teaching. A qualitative research design with Focus Group Discussion (FGD) and observation data gathering tools was employed. The study revealed that teachers hold positive beliefs on teaching grammar and reading in an integrated way, but their beliefs were not reflected in the classroom. The key finding of this paper was that teachers strongly believed in the usefulness of the integration of grammar and reading, but there were difficulties to reflect it in practice. This paper suggests that an alternative technique should be developed on discrete ways of teaching to allow teachers to practise their beliefs either on the existing text or through adapting the textbook. The findings of the study may have important implications for EFL (English as a Foreign Language) teachers and practitioners.
\end{abstract}

KEY WORDS: TEACHERS' BELIEFS, TEACHING GRAMMAR AND READING, PRACTICES, INTEGRATED TEACHING

\section{Introduction / The purpose and the rationale of the research}

This research is based on the premise that EFL teachers' beliefs and practices in terms of teaching reading and grammar in an integrated way could be important in language teaching. The main objective of this research was to assess teachers' beliefs and practices in terms of teaching grammar and reading in an integrated way at secondary school level in Ethiopia. Even though there are several findings on the integration of macro skills (listening, speaking, reading and writing), there is a scarcity of studies that address teaching grammar and reading in an integrated way. Borg and Burns (2008) explored the beliefs of ELT (English Language Teaching) professionals regarding the integration of grammar with other skills in adult classrooms. Their study reported on about 176 English language teachers from 18 countries (North and South America, Europe, Australia and Asia). However, they excluded Africa. Most of their participants had exposure to the 
ELT context. They acknowledge the findings reported in their paper are not based on classroom observation, but, rather, on "teachers' stated beliefs and their reported classroom practices" (p. 480). The current study is designed to reveal teachers' beliefs and practices in terms of teaching reading and grammar in an integrated way, diverging from Borg and Burns's (2008) design in two major aspects. They conducted their research with teachers in the context of ELT, excluding Africa, and used a self-reported questionnaire. The current study, however, conducted research with Io participants from Ethiopia, Africa, who have not so much been trained in ELT as they have in EFL. Moreover, unlike Borg and Burns (2008), the current study used observations complemented with a Focus Group Discussion to gauge participants' beliefs.

This study focuses on EFL teachers' beliefs and practices in terms of teaching reading and grammar in Grades 9 and $\mathrm{ro}$ in an Ethiopian context. The rationale for this choice is the following: in Grade 9 students start learning all subjects (e.g., chemistry, biology, history, etc.) for the first time in English. Before Grade 9, they use their native language (which most often is not English) as a subject. As English teaching and learning is a new experience for the students, the EFL teachers have a resonsibility to familiarize and inspire the students with the language. Grade Io is a turning point for the students because they take a national examination of Io subjects prepared in the English language. Succeeding in an examination will help the students to gain a place at university and compete for a scholarship. Therefore, EFL teachers of Grade ro carry a considerable responsibility to prepare students for these examinations: not only do they carry responsibility to teach the subject of English, they are also responsible for preparing the students to function in the English-based educational setting. Knowledge of the English language in general, and reading and grammar skills in particular, play an indispensable role in achieving good results in the examination. This also appears clearly from the fact that the English language examination is dominated by grammar and reading parts. The other reason for choosing Grade 9 and Grade Io is the similarity of the textbooks used in terms of content. There is no content variation between the two, but the difference is in their depth and coverage.

In addition to the observations above on the importance of Grades 9 and Io, there was a survey conducted by the Ministry of Ethiopian Education (henceforth MoE) which reported that in general secondary school teachers are poor in terms of quality and motivation (MoE, 2017). Because EFL teachers' status is among the priority concerns of the MoE in this survey, it seems reasonable to explore EFL teachers' beliefs and practices in terms of teaching grammar and reading in an integrated way. Moreover, it is believed that teachers' beliefs might be one factor which could affect the process of teaching grammar and reading (Pajares, 1992). As teaching is related to a teacher's personal beliefs, it is of paramount importance to study the relationship between teachers' beliefs and practices of teaching grammar and reading in an integrated way. Consequently, in order to attain the aim of this research, the following questions were designed: (I) What are the teachers' beliefs about teaching grammar and reading in an integrated way, and (2) Are those beliefs reflected in their teaching practice in the classroom? 


\section{Literature review}

Teachers' beliefs

The beliefs teachers hold are decisive to their teaching techniques. A central idea which has emerged from research on teacher cognition in both mainstream and language education is that teachers' thinking and practice are guided by a set of beliefs which are personal, practical, tacit, systematic and dynamic (Borg, 2006). However, understanding the relationship between teachers' beliefs and practices is considered a complex phenomenon and a messy construct: "A few would argue that the beliefs teachers hold influence their perceptions and judgments, which, in turn, affect their behavior in the classroom, or that understanding the belief structures of teachers and teacher candidates is essential to improving their professional preparation and teaching" (Pajares, I992: 307). Hence, it is not surprising that this area of research is making an impact in language teaching. In spite of the increasing attention devoted to language teacher beliefs, research on preservice and in-service language teachers is still relatively scarce (Borg, 2006).

No area of second and foreign language learning has been the subject of as much empirical and practical interest as grammar teaching (Crystal, I996; Ellis, 2002; Thornbury, 1999; Nassaji and Fotos, 2004). Grammar is not an independent element or self-sufficient area (Swan, 2002). It is more realistic to regard grammar as an accumulation of different elements, some more systematic than others, some linked together tightly or loosely, some completely independent and detachable (ibid). In their study, Jean \& Simard (20II) conclude that grammar teaching/learning is salient, but teachers and learners do not enjoy doing it. Some EFL teachers think that grammar is essentially about word usage in which students or teachers should work to split those words. Others do not enjoy grammar teaching thinking that it is a baggage of rules and is therefore boring. De Capua (2008: I) reflects on grammar, stating that:

[f]or native speakers of any given language, grammar often represents to them the great "mystery" of language, known only to language specialists or those of older generations, the ones who really know what is "right". Grammar is also often linked to both explicit and implicit criticisms of people's use or "misuse" of language, which may have created a sense of resentment or frustration with the notion of grammar.

Loewen et al. (2009) conclude that grammar teaching is generally perceived to be useful for language production. Long (I99I) defined two types of grammar teaching based on the degree of integration between meaning-focused and form-focused instruction: focus on forms (FonFs) and focus on form (FonF). Long (2000) raised the issue of FonFs in grammar teaching in which language is divided into isolated linguistic units taught in a sequential way via explaining grammar rules and error corrections. FonF is defined as 'overtly drawing attention to linguistic elements as they arise incidentally in lessons whose overriding focus is on meaning or communication' (Long, I99I: 45-46). The Focus-on-Meaning approach is based on avoiding direct grammar teaching and explicit error correction (Krashen and Terrell's, 1983). Instead, it encourages an indirect way of gaining knowledge of the language by adequate exposure. Bernat \& Lloyd (2007) state that the most important part of learning a language is the learning of its grammar. 
With regard to reading, a broad concept, it is important to define the notion of teaching a reading perspective. According to Kern (2010), it "combines a focus on language use in social contexts [...] with an additional component of active reflection on how meanings are constructed and negotiated in particular acts of communication" (Kern, 2010: 39). In the field of reading, the key role played by teachers in enabling students to learn effectively is also recognized. According to the International Reading Association (IRA, 2007), effective teachers of reading are knowledgeable, strategic, adaptive, and reflective, which means they understand both the science of reading and how to use engaging and motivating learning strategies. For Kern (2010), all the concerned bodies are responsible for the focus on preparing learners for full participation in societies that increasingly demand multilingual, multicultural, and multi-textual competence. As one way to achieve those competences, teachers should support students to read a high-level text, firstly by preparing them to comprehend the text as it is read aloud, and then by giving them meaning cues to recognize and understand the wordings within each sentence (Rose, 2006).

\section{Teaching grammar and reading in an integrated way}

Today, there is one prevailing thought that almost all language teachers share about language teaching: teaching grammar in an isolated way is not "effective" (Borg and Burns, 2008). As early as the I970s, several researchers and methodologists noted that the teaching of language skills cannot be conducted through isolable and discrete structural elements (Stern, 1992). But, most of them focused on the macro-level (listening, speaking, reading and writing) integration while rarely working on the integration with grammar. The very term 'grammar' itself means different things to different people. For example, Crystal suggests that grammar is "the business of taking a language to pieces to see how it works" (2004: I0) and "traditionally, this has involved focusing on morphology, the structure of words, and syntax, the structure of sentences" (Carter and McCarthy, 2006: 2).

An integration of grammar with reading could be the base for the students' language improvement as well as teachers' productivity and efficiency. Kuzborska (20II) concludes that beliefs which were identified as congruent with the practices of most teachers reflected a skill-based approach to reading instruction, emphasizing vocabulary, reading aloud, translation, and whole-class discussion of texts. A recent study concluded that "learning about grammar can improve pupils' critical reading and writing skills" (Aarts 20I9, p. 3).

Application of the idea of integrated skills is present in a range of linguistic and methodological frameworks for integrating grammar work in L2 learning process. Language teaching and learning recognize that, in meaningful communication, people do no employ incremental language skills in isolation. For example, to engage in a conversation, one needs to be able to speak and comprehend at the same time. To make language learning as realistic as possible, integrated instruction has to address a range of L2 skills simultaneously, all of which are requisite in communication. For instance, teaching reading can easily be tied to instruction on writing and vocabulary, and oral 
skills readily lend themselves to teaching pronunciation, listening, and cross-cultural pragmatics (Hinkel, 200I; Lazaraton, 200I; McCarthy \& O’Keeffe, 2004 as cited in Hinkel, 2006). Teachers could promote learners' noticing how particular grammar and lexis are employed in authentic written text and discourse, and select readings from a wide array of genres, such as narrative, exposition, or argumentation (ibid.).

\section{Language teaching in Ethiopia}

In Ethiopia, there have been few studies on teachers' beliefs and practices in terms of teaching reading and grammar in an integrated way, but Regassa \& Teshome (2015) found that teachers' beliefs about reading development diverge from their actual practices. At secondary school level in Ethiopia, the language curriculum is not informed by practical approaches i.e., it is theoretical and it fails to prepare students for the world of work (MoE, 2017). The teachers' method of teaching is traditional and teacher-centered, as teachers' talking time (TTT) dominates the classroom. Teachers are relatively uncreative and unaware of the fact that they can practice an integration between grammar and reading. The dominant position of English language serving as a medium of instruction in all levels of education and of communication in diplomacy and commerce has been well established since the Imperial period, mainly from I940 to I96os in Ethiopia (Tekeste, 2006). Teachers in general and teachers of EFL in particular should be aware of the ideology and politics imposed on the language policies and the curriculum. English was given as a subject of study in primary schools at the beginning of the twentieth century, and later from the I940s to the I960s it became the medium of instruction from primary to tertiary level of education (Heugh et al, 2007). However, Ethiopian teachers are poor in the use of the English language, because English is "a foreign language and, hence, they have no opportunity to practise" (Heugh et al., 2007: 107).

In the Ethiopian context, as far as the first author's reading is concerned, grammar and reading have been taught in almost all schools including primary schools. There are many complaints from different stakeholders on the quality of English. Students hardly communicate and convey meanings in real communications due to an apparent gap in their knowledge of the grammar of English and due to poor reading strategies. Teachers, when asked to write a letter, draft it several times because their grammar, cohesion and coherence skills are low. Teachers are dissatisfied with their own grammar capacity, and less confident to convey the meaning accurately and in a way that is lexico-grammatically correct. For instance, they misuse active and passive voices both in spoken and written communications which can unintentionally offend listeners and readers of their materials. Their knowledge of reading strategies and methodologies is poor, a shortcoming which critically affects the education they offer. These problems seem to be the result of a failure to focus on integrating their practices of teaching reading and grammar. For this, Mitchell (2000: 27) suggests that 'grammar teaching needs to be supported and embedded in meaning-oriented activities and tasks, which give immediate opportunities for practice and use'. As teachers' beliefs influence their goals, procedures, materials, classroom interaction patterns, their roles, and their students (Pajares, I992). 
In the Ethiopian context, teaching reading and grammar in an integrated way could benefit teachers and students from at least four perspectives (and arguably more than that). Firstly, students will understand and learn the uses of grammar through reading, albeit implicitly. For instance, the teacher never asks what the passive voice is or the present simple while the text presents the reporting of a 'bank robbery' to the police. Secondly, students could get the opportunity to understand the gist or the specific idea of the passage that is read while working on some grammatical items in the text. For instance, the teacher asks the students to identify verbs of reporting or prepositions in the paragraph. This helps noticing the relationship of 'reporting verbs plus a that-clause complement' (e.g., ... say that ..., ... report that ..., ... claim that...). The third benefit of teaching in an integrated way comes from the use of diversified elements. Students learn more effectively from differences rather than from repetition and homogeneity. Lastly, teachers, students, as well as curriculum designers effectively use their time, energy and space by minimizing, if not avoiding, discrete ways of teaching and learning.

As there are only few studies that examine teachers' beliefs and practices in terms of teaching reading and grammar in an integrated way, the present small-scale research is an attempt to add to the literature about the complex phenomenon of teacher beliefs and practices of teaching grammar and reading in Ethiopia.

\section{Methodology}

Research design

This study aims to investigate EFL teachers' beliefs and practices in terms of teaching grammar and reading in an integrated way. Qualitative inquiry is valuable to this study for two main reasons. First, qualitative research, being a naturalistic approach, allows the exploration of phenomena in context-specific settings (Creswell, 2007). Second, the study utilizes an exploratory and a descriptive method which enables the attainment/ acquisition of basic information. A qualitative research methodology was chosen because it best facilitates the construction of an in depth understanding of the details of what is to be studied. Because the study investigates beliefs and practices of teaching grammar and reading, it gives an opportunity to observe the extent to which teachers' beliefs are reflected in the classroom.

\section{The research sites}

The investigation was conducted in six secondary schools (Grade 9 and Grade Io) of Jimma Zone in Oromia Regional State in the 2017/18 academic year. Here are the main reasons for selecting these six schools:

I) Participatory-as there were not many female language teachers, the school selection was made to include women.

2) Proximity - compared to the other zones in Oromia, Jimma is relatively near to the working area of the main researcher. This enabled the researcher to manage data collection by visiting the areas.

3) Accessibility - the main researcher is a teaching staff member of Jimma University, 
which provided an opportunity to work with teachers who were ex-students of the University. This has helped establish a rapport with the respondents in the woredas ('counties' in English).

4) At the time of data collection, there was civil unrest at the research site. Because of this, trust in the main researcher was decisive in participation as well.

\section{The research sites and participants}

Six different counties were chosen as research sites from Jimma zone in Oromia Regional State (cf. the Figure I below). The selection of the research sites and participants was made purposefully, and some of the participants allowed us to capture their practice by videotape recording and pictures. The ro EFL teachers who participated in the FGD and the classroom observation had different levels of experience of teaching (cf. the Table I). Translations and transcriptions were made for each participant. Table I presents their name, sex, teaching experience, qualifications, the school and grade they teach in and the observation time. The participants' names are pseudonyms and the school names are fittingly written.

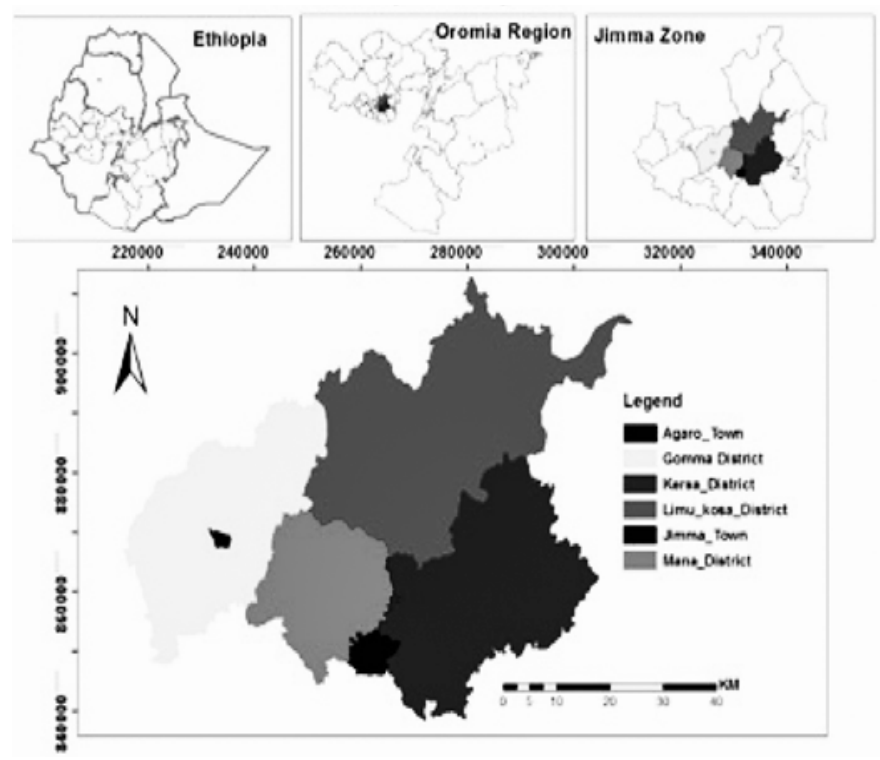

Figure 1: Research sites 


\begin{tabular}{l|l|l|l|l|l|l|l}
\hline No. & Name & Sex & $\begin{array}{l}\text { Teaching } \\
\text { experience }\end{array}$ & Qualification & $\begin{array}{l}\text { Secondary } \\
\text { School }\end{array}$ & Grade & Observed time \\
\hline 1 & Dadhi & M & 4 years & B.Ed & Yabbuu & 9 & $45 \mathrm{~m}^{\prime}$ \\
\hline 2 & Jaba & M & 28 years & B.Ed & Gembee & 9 & $40 \mathrm{~m}^{\prime}$ \\
\hline 3 & Barite & F & 29 years & B.Ed & Gembee & 9 & $37 \mathrm{~m}^{\prime}$ \\
\hline 4 & Tola & M & 35 years & B.Ed & Aggaroo & $9 / 10$ & $40 \mathrm{~m}^{\prime}$ \\
\hline 5 & Kadir & M & 18 years & B.Ed & Sarboo & 9 & $40 \mathrm{~m}^{\prime}$ \\
\hline 6 & Ganame & F & 34 years & B.Ed & Sarboo & 9 & $45 \mathrm{~m}^{\prime}$ \\
\hline 7 & Bontu & F & 24 years & B.Ed & Jireen & 9 & $45 \mathrm{~m}^{\prime}$ \\
\hline 8 & Lense & F & 30 years & B.Ed & Saqqaa & $9 / 10$ & $38 \mathrm{~m}^{\prime}$ \\
\hline 9 & Hora & M & 20 years & B.Ed & Aggaroo & $9 / 10$ & $45 \mathrm{~m}^{\prime}$ \\
\hline 10 & Chaltu & M & 13 years & B.Ed & Jireen & 10 & $40 \mathrm{~m}^{\prime}$ \\
\hline & Total & \multicolumn{7}{l}{} & $450 \mathrm{~m}^{\prime}$ \\
\hline
\end{tabular}

Table1: Participants' profiles

\section{Instruments}

Classroom observations and Focus Group Discussion (FGD) were employed to collect data. Observation methodology was chosen to investigate teachers' teaching grammar and reading in an integrated way, whereas FGD aimed at probing their beliefs of teaching grammar and reading practices. Given that people do not always do what they say they do, observation is an important instrument to get direct information about teachers and classroom events (Cohen et. al, 2005). Kuzborska (20II) has attempted classroom observation as the instrument to explore what teachers practice in their classrooms. According to Nunan (1992) "there is no substitute for direct observation as a way of finding out about language in classrooms" (p. 76). Non-participant observation was conducted because, as Creswell (2009) suggests, in this way the observer does not interfere with the people or activities under observation.

\section{Data analysis and procedure}

The study employed a qualitative data analysis approach by combining deductive and inductive methods. Lincoln and Guba (1985) suggest that employing deductive and inductive data analysis is advisable for performing data gathering and analysis simultaneously during fieldwork. The existing frameworks from the literature (e.g., Grabe, 2009; Hudson, 200I; Krashen, I993; Urquhart \& Weir, I998) support the notion that employing deductive and inductive analysis approaches increases the quality of qualitative data. For instance, to analyze the beliefs of teachers about teaching grammar and reading, the deductive approach was important. The current study also employed inductive data analysis to better investigate the practices of the teachers in relation to the question of whether or not they integrate grammar and reading. Once data gathering tools were identified, they were organized in a systematic and logical way. The replies, 
field notes, transcripts and discussions were constructed with a high degree of care during the FGD. The observation was held in a friendly manner to inspire the teachers to teach in their own way.

After obtaining a letter of permission from Jimma zone education office, Jimma University and Ghent University, the researcher officially invited the school principals and the participants to briefly discuss the aim of the study. During this meeting, the researcher explained the aim of the research in general and the contribution of the participants in particular. Finally, after discussion all of them agreed to participate in the Focus Group Discussion and classroom observations to achieve the purpose of the study.

\section{The results of the study}

\section{Teachers' background data and related issues}

Teachers' profiles revealed that they had different levels of teaching experience (the minimum 4 and the maximum 35 years). The proportion of female to male language teachers participating in the study is $4: 6$. Although English language teachers with a minimum requirement of a first degree were scarce, the study involved only the firstdegree holders, (BEd). In fact, most of them upgraded their qualification from lower levels (e.g., Teachers' Training Institute, TTI). Regarding experience, all the teachers had the experience of teaching the two Grades ( 9 and 10 ). This had advantages for the study as it enabled us to obtain nearly similar understanding about the Grades. The participants' profile showed that their experience included teaching at the primary levels as well. Except for 2 participants, most of them had less than 3 grammar courses in college. The participants reported that there have been several reasons that caused teachers' beliefs not to be reflected in the class (e.g., lack of training, insufficient knowledge, limited experience and scarcity of resources).

\section{Results of the Focus Group Discussion (FGD)}

This section presents the summary of the results of the FGD collected from Io discussants (cf. Table I). Most of the discussants (8/Io) reported that for a number of reasons they believed in teaching grammar and reading in an integrated. Firstly, all agreed that teaching reading and grammar helps students to achieve success in examinations both in a classroom and at national level. From their experience, a large portion of the examination was prepared on the basis of reading stretches of text (comprehension, matching of vocabularies, references and inferences). In addition, a few reported that they had experience in a national examination preparation as well. Therefore, teaching reading and grammar effectively triggers students for success in the examination and motivates teachers as well. "The success of students in examination could be the causes for teachers' motivation", said Jaba. Participants believed grammar and reading are the foundations of knowledge development.

Secondly, they said that teaching grammar is all about learning and teaching networking. It is about how words work in relation to one another to make a meaning of that word, sentence, paragraph, and also at whole-text levels. They were of the opinion that grammar 
could come into the reading or with the reading, but they stressed that they had limited experience and little exposure to practice it. Instead, they practiced grammar drills and explaining the rules, whereas when teaching the reading, they focused on theories (e.g., purposes, types and models of reading). Chaltu reported:

I believed in teaching grammar and reading, but separately. I encountered many problems.

The grammar sessions were boring and mechanical, which reduces students' chances to use the language in lifelike situations.

Participants ( $7 / \mathrm{IO}$ ) expressed teaching reading and grammar are the keys in language teaching itself. "Teaching grammar and reading in the language are like the central nervous system", said Tola. In his belief, if there was no grammar and reading, it would be impossible to convey our message, tasks and education to students. "Reading and grammar are essential, as they help to discover new knowledge from others", said Dadhi. He believed they were crucial to help students become part of today's global communication. All of them agreed that grammar and reading are invaluable language components, especially for teachers and students in EFL contexts. They stressed no one could use a language without reading and grammar. "The world belongs to the effective readers and the competent grammar users," said one of them. Grammar and reading were regarded helpful in different directions, but most of the participants reported they are 'unfamiliar' with an integrated way of teaching. They believed that having a good knowledge of grammar and reading is essential and that teaching in an integrated way matters. For example, they reported that the ability to integrate reading and grammar helped to understand the materials from the academy, such as magazines, poems and newspapers.

Teachers' beliefs could affect the experience of teaching. 6 discussants reported they have been teaching grammar and reading as they were taught themselves as students. Although some of them had considerable teaching experience, they were not confident about teaching grammar and reading. Most of them (8/10) stated they dreamed of teaching reading and grammar effectively, but they failed to do so. With regard to teaching materials, they (8/Io) criticized the textbook as affecting their teaching negatively. They all agreed the materials were poorly organized to practise in an integrated way. On top of that, the texts are unattractive and irrelevant to the students' background. "Teaching imported reading texts by itself has an impact on their beliefs", said Barite. They stressed most of the reading texts were imported from foreign cultures and traditions. This could negatively affect students' learning since the texts are not connected to their prior knowledge. For example, there were contents about the wedding, eating and dancing ceremonies of Hong Kong and China. Barite raised that it is good to learn about Chinese culture through reading and grammar, but the text should be adapted to the students' local context. In addition, there should be a reading text that enables to exercise students' consciousness and reservations about cultural disparities. "The textbook is full of biased and controversial stories, in which nations and nationalities of Ethiopia are treated unequally (e.g., Grade 9, p. I55 \& I8I)", said Kadir. Some participants (3/Io) also reported their 
worries that some of the contents are full of political issues. They said this could affect their beliefs about teaching directly or indirectly. In general, they stressed the textbooks have contributed to the failure of teaching in an integrated way.

Despite the fact that most of them (8/I0) reported the importance of teaching grammar and reading in an integrated way, they believed they rarely put it into practice. They ( $9 / \mathrm{Io})$ agreed they taught grammar and reading in isolation. They explained there have been numerous reasons for this (insufficient training, materials, low knowledge and limited experience). One reason that affected teaching in various ways was outdated and limited skills. Teachers need to improve their skills over time. Here, one of them spoke:

Grammar and reading teaching in foreign language are like backbone. Missing to teach those 2 is like missing the key parts in language ideology. It is not only about teaching grammar and the reading, but it affects the entire process. Although I believe this theoretically, I have limited skill to practice it.

They admitted their beliefs and practices are mostly incongruent. There were times when they did not realize the existence of inconsistency between their beliefs and practices (e.g., in implementing the grammar teaching methods and reading strategies). Some of the participants regretted that the failure to teach effectively has a direct connection with the failure of the students in language general competence. In general, the results of the FGD reported they had strong beliefs about teaching grammar and reading in an integrated way. It seemed some of the teachers' beliefs about teaching reading and grammar were strongly linked with preparing the learners for the national examination - and did not go beyond this objective. The results also suggested lack of experience, shortage of knowledge/skills, scarcity of training, and the nature of imported texts were the main blocking factors to practice the teachers' beliefs.

\section{Result of classroom observation}

The next tool briefly presents the summary of the results of the observations. The observations were conducted in the second semester of 20I7/I8 with Io EFL teachers (cf. Table I). An observation is a systematic method of collecting data that relies on a researcher's ability to gather data through his or her senses (O'leary, 2004: I70). Table 2 below summarizes how teachers were teaching grammar and reading on the basis of observations in 12 lessons for a total of 450 minutes, held from 7 th May to Ioth June 2018.

Although the information in Table 2 gives the data from ro participants, the description presents only 2 participants as sample. As a more detailed illustration, what follows is an analysis of the classroom activities of two observees teaching reading (working with the reading texts "The World in Danger" and "Different forms of Energy"). After that, a general summary of the results of the observation will be presented.

The first observee started the lesson by shortly revising the previous topic which was about 'speaking' before raising the topic of the day's lesson. He reminded students that an activity was assigned as homework, but no feedback was given. "Have you done it?", he asked. There was no clear reply heard from the students. Then, he immediately 


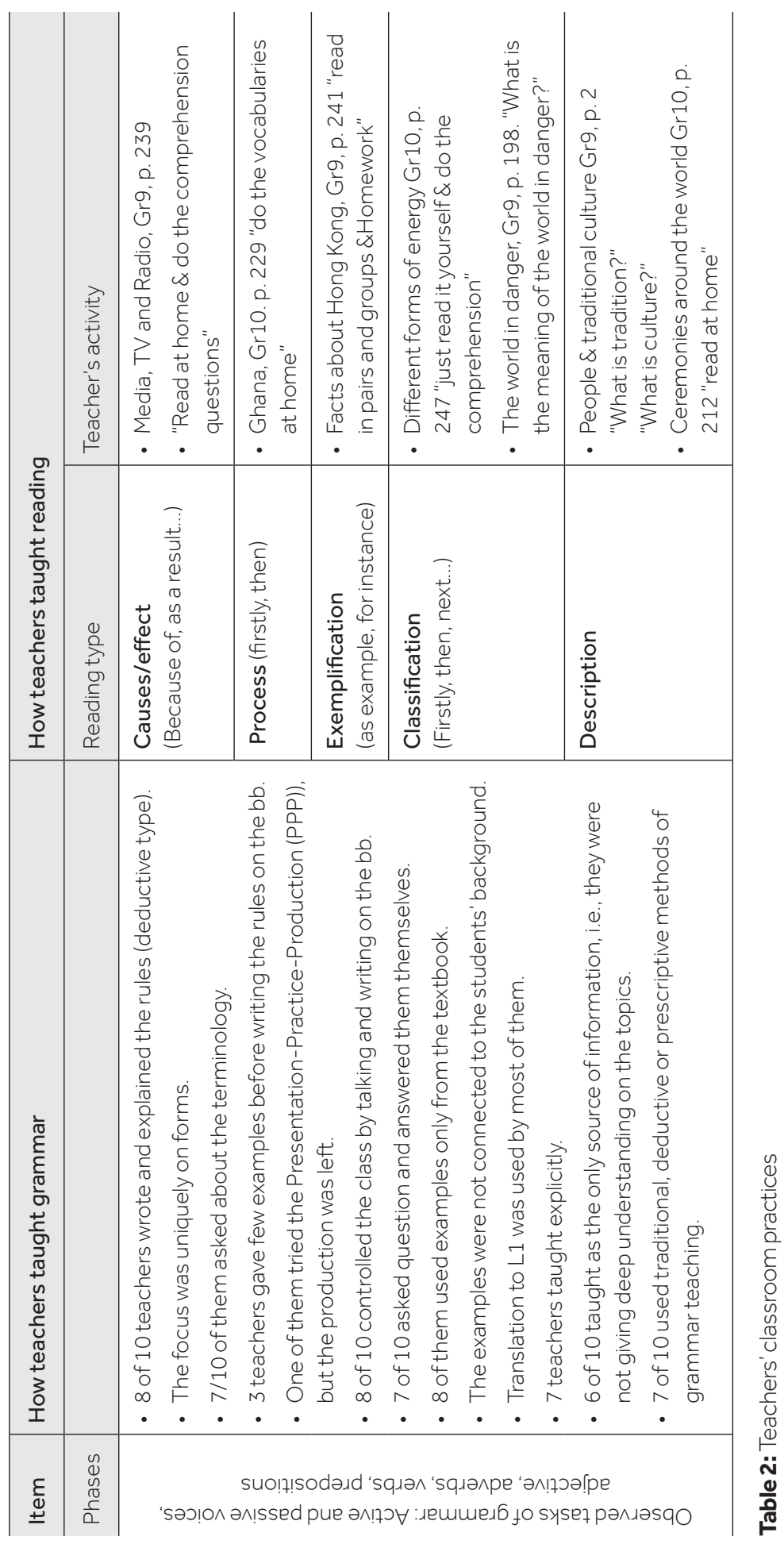


introduced the day's lesson entitled 'The World in Danger'. After he had written the reading title on the blackboard, he asked the students to pronounce the words 'world and danger' one by one after him. "Say world", he said. Then, the class shouted the word 'world'. He also asked the class to repeat the word "danger" after him. After that, the teacher quickly explained the meaning of some words related to the reading title. To brief some, he elaborated on the reading passage about animals which were under threat of extinction. The observation revealed the teacher mentioned that the animals called 'rhinos' are a good example. He was also observed listing some connecting words from the passage (e.g., firstly, then, next, today, ...). Despite the fact that the teacher seemed in a hurry, he tried to touch upon different language components (e.g., vocabulary, pronunciation, and different grammatical items). However, there was no evidence seen to practice teaching reading and grammar in an integrated way. On the one hand, the teacher was observed summarizing a lot of information from the text in a short time. On the other hand, the observation showed he rarely checked the status of the students. For instance, it was not clear who pronounced the words (world and danger) correctly and who pronounced them incorrectly. Although the teacher listed connecting words, these were not seen in sentences. It was confirmed that most of the students had no textbooks to follow him. According to the results of the observation, although what he was teaching contained different language competencies, it seemed the teacher did not address them sufficiently and clearly. Lastly, the teacher gave assignments and advised the students to refer to a dictionary, in case this was necessary. Finally, the observation of this lesson showed the teacher was teaching different language components in his approach to teaching reading, but rarely the teaching of grammar and reading was seen to be integrated. It was noticed that students were hardly participating.

The second observed lesson of the analysis focused on the teacher who was teaching the reading of a text entitled 'Different forms of Energy'. This observation took place while she was teaching Grade ro. "You should improve your reading since the national exam is upcoming", she said. Opening her textbook, she requested her students to open theirs on pages 246-247. Again, she spoke some motivational words to inspire them to read. "Reading makes complete!", she said. After she had written three questions on the blackboard, she told them to ask each other those questions in pairs. Her questions were: I) What is the meaning of energy? 2) What are the uses of energy? 3) What are the sources of energy? While students discussed the questions in pairs, she wrote the following starting phrases for the answer. "The meaning of energy is... 2) The uses of energy are... 3) The sources of energy are...”. Then, she left the class by offering additional take-home tasks.

In general, the results of the observations showed that teachers taught different language competencies, but they failed to present grammar and reading in an integrated way. Instead of that, the teachers who were teaching grammar emphasized the rules, forms, terminologies, and methods of grammar teaching, whereas the teachers in the reading sessions asked some activating questions in the form of vocabularies, speaking and connecting words. But, in most cases, they assigned the reading passages to the 
students to read at home. Regarding the grammar lesson most of the teachers (6/10) preferred postponing the activities to the next days. For example, 2 of them said, "We do this next time.". Moreover, the lessons were dominated by the teachers with almost zero participation from the learners when compared to the reading. In the reading lessons, students were at least given a question but another problem here was that there was rarely any feedback on their responses. Finally, the result of the observations showed most of the teachers (9/10) hardly taught grammar and reading in an integrated way. Most of them were textbook dependent; there was no creativity in grammar teaching focusing on rules, and no authentic engagement in teaching reading.

\section{Discussion and interpretations of the study}

This study investigated the relationship between EFL teachers' beliefs and practices of teaching grammar and reading in an integrated way. The discussion focused on two emerged findings. Firstly, the study revealed that teachers hold positive beliefs on the importance of teaching grammar and reading in an integrated way. Regardless of novice or experienced teacher, sex and level of education, teachers' beliefs on the importance and value of teaching grammar and reading in an integrated way were positive. This finding is consistent with researchers who reported that teachers have strong beliefs about grammar teaching (cf. Pajares, 1992; Ellis, 2003; Thornbury, I999; Zain, M. \& Rohani, S. 2007: I; Borg, 2006, I998).

In relation to the teachers' classroom practice, the results of the study report teachers' beliefs were rarely reflected in the classrooms. Classroom observations revealed that the majority of observees' beliefs about teaching grammar and reading in an integrated way were not reflected in their actual classroom. Researchers suggest that there might be different possible reasons for the mismatch between teachers' beliefs and their classroom practices. Pajares' (I992) suggests that stated beliefs are an unreliable indicator of actual practice. Ellis (2004) argues that "teachers' complex beliefs are not always realized in the classroom", and also Basturkmen et al. (2004) found that the "relationship between the teachers' practices and stated beliefs sometimes varies" (p. 243). The current findings are consistent with Borg and Burns (2008), Larsen-Freeman (2003) and Ellis (2006) in that teachers lacked the skill of teaching grammar with other skills in integrated ways. Larsen-Freeman (2003) stresses the job of the teacher is to combine various means of instructional options. The only congruity perceived between teachers' beliefs and practices were encouraging words to participate in learning. Mitchell (2000: 27) highlights that "grammar teaching needs to be supported and embedded with meaning-oriented activities and tasks, which give immediate opportunities for practice and use". According to Akbari (20I4), if language teachers aim at helping students read better and comprehend faster, they are advised to increase the grammatical knowledge through diverse means such as focus on form and explicit instruction.

Similarly, Grabe $(2005,2009)$ and Jeon \& Yamashita (2014) found that regardless of the language to be learnt, successful reading comprehension is dependent on the grammar the reader knows, i.e. grammar plays a very important role in understanding texts, both 
for the first language (LI) and for the other languages. The results of this study revealed that grammar teaching is still given low attention and less value in teaching, especially for non-native teachers. However, it seems clear from the evidence that grammar is important. Ellis (2006) found that several areas in teaching grammar remain the focus of debate in terms of what, how and which grammar to teach. Unfortunately, the participants within this sample hardly accommodate integrative ways of teaching grammar and reading in their classrooms. The majority was observed giving reading as a homework and postponing grammar exercises. Finally, it was evident from the FGD report that participating teachers had strong beliefs about teaching grammar and reading, but the observation lesson showed their beliefs were not reflected in their teaching practice.

\section{Conclusion}

This study examined the EFL teachers' beliefs and practices in terms of teaching reading and grammar in an integrated way in secondary schools in Ethiopia. It concluded that the majority of the participants hold strong beliefs about teaching grammar and reading, but their beliefs are not reflected in the classroom. Language teachers teach in accordance with their theoretical beliefs and differences in theoretical beliefs may result in differences in the nature of literacy instruction (Borg, 2003; Borg, 2006). It was revealed in this study that having complex beliefs about the integration of grammar and reading alone does not guarantee that teachers will teach grammar and reading in integrated ways. Therefore, teachers are encouraged to minimize the factors that hinder their beliefs to be implemented in the classroom. Teachers also need an exposure to alternative instructional tools or skills to practice their positive beliefs.

Because the study employed a purely qualitative method of data collection, it might be difficult to extend the conclusions beyond the studied sample group, i.e. its generalizability is limited. It is therefore recommended that further quantitative study in this area be conducted. A follow-up to this study, which is planned, is an investigation into whether a classroom intervention changes teachers' beliefs and practices.

\section{Acknowledgements}

As this article was the part of my PhD project, it was funded by the UGent Special Research Fund (BOF) under the supervision of Professor Miriam Taverniers, Dr. Kimberley Mouvet from Linguistics Department of Ghent University and Dr. Getachew Seyum from Jimma University, Ethiopia. Lastly, I thank all EFL secondary school teachers of Jimma Zone, Oromia Region, Ethiopia, who participated in this study. 


\section{References}

Aarts, B. (20I9). Teaching English grammar: The Englicious approach. Languages, Society and Policy https://doi.org/I0.17863/CAM.40155.

Akbari, Z. (2014). The role of grammar in second language comprehension: Iranian ESP context. Procedia-Social and Behavioral Sciences, 98, I22-126.

Basturkmen, H., Loewen, S., \& Ellis, R. (2004). Teachers' stated beliefs about incidental focus on form and their classroom practices. Applied Linguistics, 25, 243-272.

Bernat, E. \& Lloyd, R. (2007). Exploring gender effect on EFL learners' beliefs about language learning. Australian Journal of Educational \& Developmental Psychology, 7: 79-9I.

Borg, S. (I998). Teachers' pedagogical systems and grammar teaching: A qualitative study. TESOL Quarterly, 32(I), 9-38.

- (2003) Teacher cognition in language teaching: A review of research on what language teachers think, know, believe, and do. Language Teaching, 36 (2). pp. 8I-I09. ISSN I475-3049.

- (2006). Teacher cognition and language education: Research and practice. London: Continuum.

Borg, S. \& Burns, A. (2008). Integrating Grammar in Adult TESOL Classrooms. Applied Linguistics, 29(3), 456-482.

Carter, R., \& McCarthy, M. (2006). Cambridge grammar of English: a comprehensive guide; spoken and written English grammar and usage. Ernst Klett Sprachen.

Cohen, L., Manion, L. and Morrison, K. (2005). Research Methods in Education. (Fifth Edition) London: Routledge Falmer.

Creswell, J., W. (2007). Research design. Qualitative and mixed methods approaches. London: Sage.

- (2009). Research design: Qualitative, quantitative, and mixed methods approaches (3rd ed.). Thousand Oaks, CA: Sage.

Crystal, D. (I996). The past, present and future of English rhythm. In M., Vaughan-Rees, Changes in Pronunciation, Summer 1996 Issue of the Newsletter of the IATEFL Pronunciation Special Interest Group, 8-I3.

- (2004). Making sense of grammar. Essex: Pearson.

DeCapua. (2008). Grammar for Teachers: A Guide to American English for Native and Non-Native Speakers. College of New Rochelle. New Rochelle, NY 10805.

Ellis, R. (2002). The place of grammar instruction in the second/foreign language curriculum. In Hinkel, E. and Fotos, S. (eds.) New Perspectives on Grammar Teaching in Second Language Classrooms. pp. 17-34. Mahwah, New Yersey: Lawrence Erlbaum Associates.

- (2003). Task-Based Language Learning and Teaching. Oxford: Oxford University Press.

- (2004). The definition and measurement of L2 explicit knowledge. Language learning, 54(2), $227-275$.

- (2006). Current issues in the teaching of grammar: An SLA perspective. TESOL Quarterly, 40(I), 83I07.

Grabe, W. (2005). The role of grammar in reading comprehension. In J. Frodesen \& C. Holton (Eds.), The power of context in language teaching and learning (pp. 268-282). Boston: Heinle \& Heinle.

- (2009). Reading in a second language: Moving from theory to practice. Ernst Klett Sprachen.

Heugh, K., Diedericks, G., Prinsloo, C., \& Herbst, D. (2007). Assessment of the language and mathematics skills of grade 8 learners in the Western Cape in 2006. Human Sciences Research Council: Pretoria.

Hinkel, E. (2006). Current perspectives on teaching the four skills. Tesol Quarterly, 40(I), IO9-I3I.

Hudson, R. (200I). Grammar teaching and writing skills: the research evidence. Syntax in the Schools, I7(I), I-6.

International Reading Association. (2007). Teaching reading well: A synthesis of the International Reading Association's research on teacher preparation for reading instruction. Newark, DE: Author.

Jean, G., \& Simard, D. (20II). Grammar teaching and learning in L2: Necessary, but boring? Foreign language annals, 44(3), 467-494. 
Jeon, E. H., \& Yamashita, J. (20I4). L2 reading comprehension and its correlates: A meta-analysis. Language Learning, 64(I), I60-2I2.

Kern, R., (2010). Literacy and Language Teaching. Oxford: Oxford University Press.

Krashen, S. D. (1993). The case for free voluntary reading. Canadian Modern Language Review, 50(I), $72-82$.

Krashen, S. \& Terrell, T. (1983). The natural approach: Language acquisition in the classroom. New York: Pergamon Press.

Kuzborska, I. (20II). Links between teachers' beliefs and practices and research on reading. Reading in a foreign language, 23(I), I02-I28.

Larsen-Freeman, D. (2003). Teaching language: From grammar to grammaring. Boston: Heinle.

Lincoln, Y. S., \& Guba, E. G. (I985). Naturalistic inquiry. Newbury Park, CA: Sage.

Loewen, S., Li, S., Fei, F., Thompson, A., Nakatsukasa, K., Ahn, S., \& Chen, X. (2009). Second language learners' beliefs about grammar instruction and error correction. The Modern Language Journal, 93(I), 9I-I04.

Long, M. (I99I). Focus on form: A design feature in language teaching methodology. In: K. De Bot, R. Ginsberg, \& C. Kramsch (Eds.), Foreign language research in cross-cultural perspective (pp. 39-52). Amsterdam: John Benjamins.

- (2000). Focus on form in task-based language teaching. In RD Lambert \& E. Shohamy (eds). Language policy and pedagogy: Essays in honor of A Ronald Walton. Philadelphia: John Benjamins.

Ministry of Education. (2017, November). General Education Quality Improvement Package (GEQIP). Addis Ababa, Ethiopia: Ministry of Education.

Mitchell, R. (2000). Applied linguistics and evidence-based classroom practice: the case of foreign language grammar pedagogy. Applied Linguistics, 2I(3), 28I-303. London: Prentice Hall.

Nassaji, H., \& Fotos, S. (2004). Current developments in research on the teaching of grammar. Annual Review of Applied Linguistics, 24,I26-I45.

Nunan, D. (Ed.). (1992). Collaborative language learning and teaching. Cambridge University Press.

O'Leary, Z. (2004). The Essential Guide to Doing Research: London, SAGE Publications.

Pajares, M. F. (1992). Teachers' beliefs and educational research: Cleaning up a messy construct. Review of Educational Research, 62, 307-332.

Regassa, T., \& Teshome, G. (2015). Teachers' beliefs system of teaching reading and their classroom practices: with reference to high schools of jimma and east wollega zones. International Journal of Physical and Social Sciences, 5(I), 479 .

Rose, D. (2006). Reading genre: a new wave of analysis. Linguistics and the human sciences, 2(2), 185.

Stern, H. H. (1992). Issues and options in language teaching. Oxford: Oxford University Press.

Swan, M. (2002). Seven bad reasons for teaching grammar-and two good ones. Methodology in language teaching: An anthology of current practice, I48-I52.

Tekeste, N. (2006). Education in Ethiopia: from crisis to the brink of collapse. Stockholm: Nordiska Afrikainstituet.

Thornbury, S. (1999). How to Teach Grammar. Essex: Pearson Education Limited.

Urquhart, S. \& Weir, C. (1998). Reading in a second language: Process, product and practice. New York: Longman.

Williams, M. \& Burden, R. (1997). Psychology for language teachers. Cambridge: Cambridge University Press.

Zain, M., \& Rohani, S. (2007). Teaching of Grammar: Teachers' Beliefs, Instructional Contexts and Practices. Unpublished doctoral dissertation. Kuala Lumpur, Malaysia: Universiti Kebangsaan Malaysia. 